\title{
KEWENANGAN PEMERINTAH DALAM PENGADAAN TANAH UNTUK KEPENTINGAN UMUM
}

\author{
Muwahid \\ UIN Sunan Ampel | JI. A. Yani I 17 Surabaya \\ muwahidizza@gmail.com
}

\begin{abstract}
The government, in carrying out land acquisition for the public interest, gets the authority of attribution in Law No. 5 of 1960 about the Basic Agrarian Principles (UUPA) as contained in article 2, article 6, and article 18. On the oher hands, the government also gets the attributional authority of Law No. 20 of 1961 about revocation of land rights, and Law No. 2 of 2012 about land acquisition for development of the public interest. However, in the laws and regulations governing land acquisition in the public interest, there is an inconsistency in regulation between Law No. 2 of 2012 and Law No. 20 of 196I. Several articles in Law No. 2 of 2012 deny the provisions regulated in Law No. 20 of 1961. Even though Law No. 20 of 1961 is still valid because it has never been revoked or replaced with other laws and regulations. Beside that, there is an overlapping arrangement between Law No. 2 of 2012 and Law No. 20 of 1961.
\end{abstract}

Keywords: Authority, Government, Land Procurement, Public Interest

Abstrak: Pemerintah dalam melaksanakan pengadaan tanah untuk kepentingan umum mendapatkan kewenangan atribusi dalam Undangundang Nomor 5 Tahun 1960 tentang Peraturan Dasar Pokok-pokok Agraria (UUPA) sebagaimana yang termuat dalam pasal 2, pasal 6, dan pasal 18, kemudian pemerintah juga mendapatkan kewenangan atribusi dari Undang-undang Nomor 20 Tahun 196I tentang pencabutan hak atas tanah, dan Undang-undang Nomor 2 Tahun 2012 tentang pengadaan tanah bagi pembangunan untuk kepentingan umum. Namun demikian, dalam peraturan perundang-undangan yang mengatur tentang pengadaan tanah untuk kepentingan umum terjadi inkonsistensi pengaturan antara Undang-undang Nomor 2 Tahun 2012 dengan Undang-undang Nomor 20 Tahun 1961. Beberapa pasal dalam Undang-undang Nomor 2 tahun 2012 menafikan ketentuan yang diatur dalam Undang-undang Nomor 20 tahun 1961. Padahal secara formil Undang-undang Nomor 20 tahun 1961 masih berlaku karena belum pernah dicabut atau diganti dengan peraturan perundang-undangan

AL-DAULAH: JURNAL HUKUM DAN PERUNDANGAN ISLAM

VOLUME 8, NOMOR 2, OKTOBER 2018

p-ISSN 2089-0109; e-ISSN 2503-0922

Homepage: http://jurnalfsh.uinsby.ac.id/index.php/aldaulah

Email: judulsj@gmail.com 
yang lain. Disamping itu terjadi overlapping pengaturan antara Undangundang Nomor 2 tahun 2012 dengan Undang-undang Nomor 20 tahun 1961.

Kata Kunci: Kewenangan, Pemerintah, Pengadaan Tanah, Kepentingan Umum.

\section{Pendahuluan}

Negara sebagai organisasi kekuasaan mempunyai kewenangan untuk mengatur peruntukan dan penggunaan tanah yang ada di wilayahnya, hal itu sebagaimana tertuang dalam pasal 2 Undang-undang Nomor 5 Tahun 1960 tentang Peraturan Dasar Pokok-pokok Agraria, selanjutnya disebut UUPA. Salah satu kewenangan yang diberikan oleh undang-undang kepada pemerintah sebagai penyelenggara negara adalah melakukan pengadaan tanah bagi pembangunan yang tujuannya untuk kepentingan umum. Selain dari Pasal 2 UUPA pemerintah juga mendapatkan kewenangan atribusi untuk melakukan pengadaan tanah untuk kepentingan umum dari Undang-undang-Nomor 2 tahun 2012 tentang pengadaan tanah untuk kepentingan umum dan Undang-undang Nomor 20 Tahun 1961 tentang pencabutan hak atas tanah.

Perolehan tanah untuk kepentingan umum dapat dilakukan dengan mekanisme pengadaan tanah sebagaimana yang diatur dalam Undang-undang Nomor 2 Tahun 2012, dan pencabutan hak atas tanah sebagaimana yang diatur dalam Undang-undang Nomor 20 Tahun 1961. Selama ini pengaturan pengadaan tanah untuk kepentingan umum terjadi overlapping pengaturan antara peraturan perundang-undangan, yakni Undang-undang Nomor 2 Tahun 2012 dengan Undang-undang Nomor 20 Tahun 1961. Overlapping atau tumpang tindih di dalam pengaturan pengadaan tanah untuk kepentingan umum terjadi karena ketidakjelasan paradigma mengenai perolehan hak atas tanah oleh Negara untuk kepentingan umum dalam Undang-undang Nomor 2 tahun 2012.

Jika sebelum Undang-undang Nomor 2 Tahun 2012, pengadaan tanah untuk kepentingan umum dapat dilakukan 
dengan mekanisme pelepasan hak dan pencabutan hak, namun dalam rezim Undang-undang Nomor 2 Tahun 2012 menafikan mekanisme pencabutan hak atas tanah, padahal secara formal Undang-undang Nomor 2 tahun 1961 masih berlaku. Dalam tulisan ini akan diuraikan tentang konsep kewenangan pemerintah, dasar kewenangan pemerintah dalam pengadaan tanah, dan overlapping pengaturan dalam Undang-undang Nomor 2 Tahun 2012 dengan Undang-undang Nomor 20 Tahun 1961.

\section{Konsep Kewenangan Pemerintah}

Konsep kewenangan dalam hukum administrasi negara sangatlah penting, karena pemerintah baru dapat menjalankan fungsinya atas dasar kewenangan yang dimilikinya. Artinya keabsahan tindakan pemerintah didasarkan pada kewenangan yang diatur dalam peraturan perundang-undangan (legislative beginselen). ${ }^{1}$

S.F. Marbun membedakan antara kewenangan (authority) dengan wewenang (competence). Kewenangan merupakan kekuasaan yang diformalkan baik terhadap segolongan orang tertentu, maupun kekuasaan terhadap suatu bidang pemerintahan secara bulat yang berasal dari kekuasaan legislative maupun kekuasaan pemerintah, sedangkan wewenang hanya merupakan satu bagian dari seperangkat kewenangan. ${ }^{2}$ Jadi kewenangan merupakan kumpulan dari wewenang-wewenang (rechtsbevoegdheden). Dengan demikian, lingkup kewenangan lebih luas daripada wewenang. Lebih lanjut wewenang diartikan sebagai kemampuan untuk melakukan tindakan hukum tertentu, dalam arti tindakan tindakan yang mempunyai akibat hukum, dan mencakup mengenai muncul dan hilangnya akibat hukum tertentu. Wewenang tidak sama dengan kekuasaan (macht). Kekuasaan hanya menggambarkan hak untuk berbuat atau tidak berbuat,

I Sadjiono, Bab-bab Pokok Hukum Administrasi Negara, (Yogyakarta: LaksBang, 20 I I), 58.

2 SF. Marbun, Peradilan Admintrasi Negara dan Upaya Adminstratif di Indonesia, (Yogyakarta; Liberty, 1997), 154. 
sedangkan wewenang mengandung hak dan kewajiban. ${ }^{3}$ Wewenang bersumber pada asas legalitas sebagai sendi utama penyelenggaraan pemerintahan. Asas ini menggariskan bahwa sumber wewenang pemerintah dalam menjalankan pemerintahan berasal dari peraturan perundang-undangan. Pada dasarnya dalam wewenang terdapat tiga komponen pokok, yaitu; pertama, komponen pengaruh, artinya penggunaan wewenang dimaksudkan untuk mengendalikan perilaku subyek hukum; kedua, komponen dasar hukum, artinya wewenang itu harus bersumber dan berdasar pada hukum yang berlaku; ketiga, komponen konformitas hukum, artinya adanya standar wewenang, baik standar khusus atau standar umum. ${ }^{4}$ Wewenang pemerintah bersifat expressimplied, jelas maksud dan tujuanya, terikat pada waktu tertentu dan tunduk pada batasan-batasan hukum tertulis dan hukum yang tidak tertulis. ${ }^{5}$

Secara teoritis wewenang yang diperoleh oleh pejabat tata usaha negara dalam menjalan administrasi pemerintahan melalui tiga cara, yaitu atribusi, delegasi, dan mandat. Atribusi merupakan kewenangan yang diperoleh dari perintah peraturan perundangundangan, artinya wewenang pemerintah telah diatur dalam peratunran perundang-undangan yang berlaku (asas legalitas). Sementara delegasi kewenangan yang diperoleh oleh pejabat tata usaha negara berdasarkan pelimpahan dari organ pemerintahan yang satu kepada organ pemerintahan yang lain. Sifat wewenang delegasi adalah pelimpahan yang bersumber pada wewenang atribusi. Sedangkan mandat merupakan kewenangan yang diperoleh ketika organ pemerintah mengizinkan kewenanganya dijalankan oleh organ pemerintahan yang lain. ${ }^{6}$ Wewenang mandat umumnya terjadi dalam hubungan rutin antara atasan dan

\footnotetext{
${ }^{3}$ Ridlwan HR, Hukum Administrasi Negara, (Jakarta: PT. Rajagrafindo Persada, 20I I), 99.

${ }^{4}$ Sadjiono, Bab-bab Pokok...,59.

5 SF. Marbun, Peradilan Admintrasi..., I 54.

${ }^{6}$ Ridlwan, Hukum Administrasi..., 102.
} 
bawahan, kecuali dilarang secara tegas oleh peraturan perundangundangan.

Pelimpahan wewenang melalui delegasi dilakukan dengan syarat-syarat berikut:

a. Delegasi harus definitif dalam artinya pemberi delegasi tidak dapat lagi menggunakan sendiri wewenang yang telah dilimpahkan itu;

b. Delegasi harus berdasarkan ketentuan peraturan perundangundangan yang berlaku, artinya delegasi hanya dimungkinkan kalau ada ketentuan untuk itu dalam peraturan perundangundangan;

c. Delegasi tidak kepada bawahan, artinya dalam hubungan hirarkhi kepegawaian tidak diperkenankan delegasi;

d. Kewajiban memberikan keterangan, artinya pemberi wewenang (delegans) berhak untuk meminta penjelasan tentang pelaksanaan wewenang tersebut. ${ }^{7}$

Perbedaan antara delegasi dan mandat sebagai berikut; pertama, dilihat dari prosedur pelimpahanya; wewenang delegasi berasal dari organ pemerintahan kepada organ yang lainya yang dilakukan dengan peraturan perundang-undangan. Sedangkan mandat pelimpahan wewenang terjadi dalam hubungan rutin antara atasan dan bawahan; hal biasa kecuali dilarang secara tegas; kedua, dilihat dari tanggungjawab dan tanggunggugat, wewenang delegasi tanggunggugat dan tanggungjawab beralih kepada penerima delegai (delegetaris), sedangkan mandat, tanggunggugat dan tanggungjawab tetap ada pada pemberi mandat; ketiga, dilihat dari kemungkinan pemberi menggunakan wewenang lagi, dalam wewenang delegasi, pemberi wewenang tidak dapat menggunakan wewenangnya lagi, kecuali setelah ada pencabutan dengan berpegang pada asas "contractus actus", sedangkan mandat, pemberi mandat setiap saat dapat menggunakan sendiri wewenang yang telah dilimpahkan itu. ${ }^{8}$

${ }^{8} \mathrm{lbid,}$ 107. Lihat pula S.F. Marbun, Peradilan Administrasi..., 160. 
Untuk mempermudah dalam membedakan wewenang atribusi, delegasi dan mandat berikut digambarkan dalam tabel di bawah ini: ${ }^{9}$

\begin{tabular}{|c|c|c|c|}
\hline Dilihat dari & Atribusi & Delegasi & Mandat \\
\hline $\begin{array}{l}\text { Cara } \\
\text { memperoleh }\end{array}$ & $\begin{array}{l}\text { Perundang- } \\
\text { undangan }\end{array}$ & Pelimpahan & Pelimpahan \\
\hline $\begin{array}{l}\text { Kekuatan } \\
\text { mengikatnya }\end{array}$ & $\begin{array}{l}\text { Tetap melekat } \\
\text { sebelum ada } \\
\text { perubahan } \\
\text { peraturan } \\
\text { perundang- } \\
\text { undangan }\end{array}$ & $\begin{array}{l}\text { Dapat dicabut } \\
\text { atau ditarik } \\
\text { kembali apabila } \\
\text { ada } \\
\text { pertentangan } \\
\text { atau } \\
\text { penyimpangan } \\
\text { (contactus actus) }\end{array}$ & $\begin{array}{l}\text { Dapat ditarik } \\
\text { atau } \\
\text { digunakan } \\
\text { sewaktu } \\
\text { waktu oleh } \\
\text { pemberi } \\
\text { wewenang } \\
\text { (mandans) }\end{array}$ \\
\hline $\begin{array}{l}\text { Tanggungaja } \\
\text { wab dan } \\
\text { Tanggunggu } \\
\text { gat }\end{array}$ & $\begin{array}{l}\text { Penerima } \\
\text { wewenang } \\
\text { bertanggungja } \\
\text { wab mutlak } \\
\text { akibat yang } \\
\text { timbul dari } \\
\text { wewenang }\end{array}$ & $\begin{array}{l}\text { Pemberi } \\
\text { wewenang } \\
\text { (delegans) } \\
\text { melimpahkan } \\
\text { tanggungjawab } \\
\text { dan } \\
\text { tanggunggugat } \\
\text { kepada } \\
\text { penerima } \\
\text { wewenang } \\
\text { (delegetaris) }\end{array}$ & $\begin{array}{l}\text { Berada pada } \\
\text { pemberi } \\
\text { mandate } \\
\text { (mandans) }\end{array}$ \\
\hline $\begin{array}{l}\text { Hubungan } \\
\text { wewenang }\end{array}$ & $\begin{array}{l}\text { Hubungan } \\
\text { hukum } \\
\text { pembentuk } \\
\text { undang- } \\
\text { undang } \\
\text { dengan organ } \\
\text { pemerintahan }\end{array}$ & $\begin{array}{l}\text { Berdasarkan } \\
\text { atas wewenang } \\
\text { atribusi yang } \\
\text { dilimpahkan } \\
\text { kepada } \\
\text { delegetaris }\end{array}$ & $\begin{array}{l}\text { Hubungan } \\
\text { bersifat } \\
\text { internal } \\
\text { antara } \\
\text { bawahn dan } \\
\text { atasan }\end{array}$ \\
\hline
\end{tabular}

9 Sadjiono, Bab-bab Pokok...,67. 
Dengan demikian, tindakan pejabat tata usaha negara dalam menjalankan tugasnya harus berdasar kepada kewenangan yang ada baik yang berdasar pada kewenangan atribusi, delegasi atau maandat, jika pejabat tata usaha menjalankan pemerintahan tidak berdasakan pada kewenangan yang ada, maka dapat dikatakan tindakan tersebut melampaui kewenangan atau menyalahgunakan kewenangan (detournement de pouvoirlabuse of power). Untuk mengetahui berwenang atau tidaknya pejabat tata usaha negara dalam melakukan tindakan pemerintahan, melalui langkah penafsiran sistematis terhadap ketentuan perundang-undangan yang berlaku, khususnya yang mengatur tentang wewenang pemerintahan. Pangkal tolak penilaian kewenangan tindak pemerintahan kembali pada asas legalitas (ligaliteit beginselen) sebagai asas utama dalam Negara hukum. ${ }^{10}$

\section{Dasar Kewenangan Pemerintah dalam Pengadaan Tanah}

Pemerintah dalam melakukan kebijakan di bidang pertanahan mengacu pada wewenang yang diberikan oleh Undang-undang. Kewenangan tersebut sebagaimana diatur dalam UUPA. Pasal 2 UUPA menentukan:

1. Atas dasar ketentuan pasal 33 ayat (3) Undang-Undang Dasar dan hal-hal sebagai yang dimaksud dalam pasal 1, bumi, air dan ruang angkasa termasuk kekayaan alam yang terkandung di dalamnya itu pada tingkatan tertinggi dikuasai oleh negara sebagai organisasi seluruh rakyat;

2. Hak menguasai dari Negara termaksud dalam ayat (1) pasal ini memberi wewenang untuk:

a. Mengatur dan menyelenggarakan peruntukan, penggunaan, persediaan dan pemeliharaan bumi, air dan ruang angkasa tersebut;

b. Menentukan dan mengatur hubungan-hubungan hukum antara orang-orang dengan bumi, air dan ruang angkasa; 
c. Menentukan dan mengatur hubungan-hubungan hukum antara orang-orang dan perbuatan-perbuatan hukum yang mengenai bumi, air dan ruang angkasa.

d. Wewenang yang bersumber pada hak menguasai dari negara tersebut pada ayat (2) pasal ini, digunakan untuk mencapai sebesar-besarnya kemakmuran rakyat, dalam arti kebangsaan, kesejahteraan dan kemerdekaan dalam masyarakat dan negara hukum Indonesia yang merdeka, berdaulat, adil dan makmur.

3. Hak menguasai dari Negara tersebut di atas pelaksanaannya dapat dikuasakan kepada daerah-daerah Swatantra dan masyarakat-masyarakat hukum adat, sekedar diperlukan dan tidak bertentangan dengan kepentingan nasional, menurut ketentuan-ketentuan Peraturan Pemerintah.

Berdasarkan ketentuan Pasal 2 UUPA tersebut negara bukanlah sebagai pemilik atas tanah yang ada di wilayah Republik Indonesia, melainkan negara sebagai penguasa. Atas dasar ketentuan Pasal 2 UUPA tersebut timbul apa yang disebut sebagai Hak Menguasai Negara, untuk selanjutnya disebut HMN. Kedudukan dan wewenang negara yang didasarkan pada HMN dipahami sebagai konsep hubungan antara Negara dengan bumi, air, ruang angkasa dan sumber daya alam lainnya sebagai hubungan penguasaan dan bukan pemilikan. ${ }^{11}$ Penjelasan Umum Angka II (2) UUPA menyebutkan:

"Undang-Undang Pokok Agraria berpangkal pada pendirian, bahwa untuk mencapai apa yang ditentukan dalam Pasal 33 ayat 3 Undang-Undang Dasar tidak perlu dan tidak pada tempatnya bahwa bangsa Indonesia ataupun Negara bertindak sebagai pemilik tanah, adalah lebih tepat jika Negara, sebagai organisasi kekuasaan dari seluruh rakyat (bangsa) bertindak selaku penguasa, dari sudut inilah harus dilihat dari ketentuan dalam Pasal 2 ayat 1 yang menyatakan bahwa bumi, air dan ruang

I Maria SW Soemardjono, Kebijakan Pertanahan Antara Regulasi dan Implementasi, Jakarta: Penerbit Buku Kompas, 2005), 57. 
angkasa, termasuk kekayaan alam yang terkandung di dalamnya, pada tingkatan tertinggi dikuasai oleh negara. Sesuai dengan pangkal pendirian tersebut di atas perkataan "dikuasai" dalam pasal ini bukanlah berarti "dimiliki" akan tetapi adalah pengertian yang memberi wewenang kepada Negara sebagai sebagai organisasi kekuasaan dari Bangsa Indonesia itu, untuk pada tingkatan tertinggi:

a. Mengatur dan menyelenggarakan peruntukan, penggunaan, persediaan dan pemeliharaan bumi, air dan ruang angkasa;

b. Menentukan dan mengatur hubungan-hubungan hukum antara orang-orang dengan bumi, air dan ruang angkasa;

c. Menentukan dan mengatur hubungan-hubungan hukum antara orang-orang dan perbuatan-perbuatan hukum yang mengenai bumi, air dan ruang angkasa."

Rincian kewenangan negara untuk menentukan, mengatur hubungan hukum, dan menyelenggarakan berbagai kegiatan dalam Pasal 2 tersebut oleh UUPA pada dasarnya merupakan suatu interpretasi otentik mengenai Hak Menguasai Negara yang dimaksudkan oleh Pasal 33 ayat (3) Undang-Undang Dasar Negara Republik Indonesia Tahun 1945, sebagai hubungan hukum yang bersifat publik semata-mata, sehingga tidak ada penafsiran lain kecuali yang telah disebutkan dalam Pasal 2 ayat (2) UUPA tersebut. $^{12}$

Selanjutnya kewenangan Pemerintah untuk melakukan pengadaan tanah untuk kepentingan umum diadasarkan pada asas bahwa semua hak atas tanah berfungsi sosial sebagaimana diatur dalam Pasal 6 UUPA yang menentukan: "Semua hak atas tanah berfungsi sosial". Penjelasan Pasal 6 tersebut menentukan:

"...Hak atas tanah apapun yang ada pada seseorang, tidaklah dapat dibenarkan bahwa tanahnya itu akan dipergunakan (atau tidak dipergunakan) semata-mata untuk kepentingan pribadinya, apalagi kalau hal itu menimbulkan kerugian bagi masyarakat. Penggunaan tanah harus disesuaikan dengan keadaannya dan sifat dari pada haknya, hingga bermanfaat bagi kesejahteraan dan

12 Boedi Harsono, Hukum Agraria Indonesia, Sejarah Pembentukan Undang-Undang Pokok Agraria, Isi dan Pelaksanaannya, (Jakarta: Djambatan, 2000), 230. 
kebahagiaan yang mempunyainya maupun bermanfaat pula bagi masyarakat dan negara, tetapi dalam pada itu ketentuan tersebut tidak berarti bahwa kepentingan perseorangan akan terdesak sama sekali oleh kepentingan umum (masyarakat). UndangUndang Pokok Agraria (UUPA) memperhatikan pula kepentingan-kepentingan perseorangan. Kepentingan masyarakat dan kepentingan perseorangan haruslah saling mengimbangi, hingga pada akhirnya akan tercapai tujuan pokok kemakmuran, keadilan dan kebahagiaan bagi rakyat seluruhnya."

Berdasarkan penjelasan Pasal 6 UUPA tersebut dapat disimpulkan bahwa di dalam hak milik seseorang itu terkandung hak dari masyarakat. ${ }^{13}$ Apabila Pasal 6 UUPA dicermati, tampak beberapa hal yang dapat dipandang sebagai sifat dari fungsi sosial hak milik atas tanah yang dimaksudkan sebagai penegasan pokok pembatasan kebebasan individu. Sifat fungsi sosial antara lain:

1. Penggunaan tanah harus sesuai dengan keadaan tanahnya, sifat, dan tujuan pemberian haknya sehingga menurut UUPA tanah yang diterlantarkan adalah bertentangan dengan fungsi sosial;

2. Penggunaan tanah harus sesuai dengan rencana yang telah ditetapkan oleh pemerintah;

3. Jika kepentingan umum menghendaki didesaknya kepentingan individu sehingga mengalami kerugian maka kepadanya harus diberikan ganti kerugian;

4. Tanah bukan barang komoditi perdagangan sehingga tidak dibenarkan menjadikan tanah sebagai objek spekulasi. ${ }^{14}$

Selain Pasal 2 dan pasal 6 UUPA, negara dalam melaksanakan pengadan tanah untuk kepentingan umum juga mendapatkan kewenangan dari Pasal 18 UUPA yang menentukan:“Untuk kepentingan umum termasuk kepentingan Bangsa dan Negara serta kepentingan bersama dari rakyat, hak-hak atas tanah dapat

13 AP. Parlindungan, Bunga Rampai Hukum Agraria Serta Land Reform, (Bandung: CV Mandar Maju, 1994), 87.

14 Yusriadi, Industrialisasi\&Perubahan Fungsi Sosial Hak Milik Atas Tanah, (Yogyakarta: Genta Publising, 20।0), 32. 
dicabut dengan memberikan ganti rugi yang layak dan menurut cara-cara yang diatur dengan Undang-undang". Penjelasan Pasal 18 UUPA menentukan: "Pasal ini merupakan jaminan bagi rakyat mengenai hak-haknya atas tanah. Pencabutan hak dimungkinkan, tetapi diikat dengan syarat-syarat, misalnya disertai dengan pemberian ganti kerugian yang layak".

Berdasarkan perintah Pasal 18 UUPA tersebut kemudian dibuat Undang-undang Nomor 20 Tahun 1961 tentang Pencabutan hak atas Tanah dan Benda-benda yang Ada di Atasnya (LN.1961288,TLN.2324). Pencabutan hak atas tanah merupakan cara yang terakhir yang dapat ditempuh setelah cara lain tidak berhasil dilakukan, misalnya dengan cara jual beli, tukar menukar atau dengan cara pelepasan hak tidak mencapai kata sepakat. Dalam melakukan pencabutan hak atas tanah pemerintah harus memberikan ganti rugi yang layak kepeda pemegang hak atas tanah. Dengan demikian, pencabutan hak atas tanah baru dapat dilakukan apabila memenuhi syarat:

1. Dilakukan untuk kepentingan umum termasuk kepentingan bangsa dan negara serta kepentingan bersama dari rakyat, dan kepentingan pembangunan.

2. Memberikan ganti rugi yang layak kepada pemegang hak.

3. Dilakukan menurut cara-cara yang diatur oleh undang-undang.

4. Pemindahan hak dengan cara biasa tidak mungkin dilakukan (misalnya dengan cara jual beli atau pembebasan hak).

5. Tidak mungkin memperoleh tanah di tempat lain untuk keperluan tersebut. ${ }^{15}$

Pencabutan hak atas tanah berdasarkan Undang-undang Nomor 20 Tahun 1961 dilaksanakan dengan prinsip:

1. Dalam keadaan mendesak untuk melakukan tindakan yang terpaksa dari pemerintah;

2. Dilakukan untuk kepentingan umum, sehingga kepentingan pribadi dikorbankan;

${ }^{15}$ Effendi Perangin, Hukum Agraria di Indonesia, Suatu Telaah dari Sudut Pandang Praktisi Hukum (Jakarta: Rjawali Press, 1991), 39. 
3. Ada rekomendasi/pertimbangan kepala daerah, Menteri Agraria, Menteri Kehakiman, daan Menteri dari instansi yang memerlukan tanah;

4. Pemberian ganti kerugian kepada pemilik tanah yang bersangkutan yang dihitung oleh panitia penaksir;

5. Pencabutan hak harus dilakukan dengan Keputusan Presiden;

6. Diberikan kesempatan untuk banding atas penetapan taksiran ganti kerugian ke Pengadilan Tinggi;

7. Diumumkan dalam berita Negara dan surat kabar. ${ }^{16}$

Pencabutan hak atas tanah dilakukan dalam kondisi ketika musyawarah untuk menentukan ganti rugi tidak tercapai, sedangkan proyek pembangunan tidak bisa dipindahkan ketempat lain, sehingga tidak ada upaya lagi selain melakukan pencabutan hak atas tanah dan benda-benda yang ada di atasnya. Namun demikian, kepada pemilik hak atas tanah yang tanahnya dicabut untuk kepentingan umum diberikan ganti rugi yang layak. Apabila pemegang hak atas tanah tidak bisa menerima ganti rugi yang diberikan oleh pemerintah, pemegang hak atas tanah diberikan hak untuk mengajukan gugatan ke Pengadilan Tinggi, putusan pengadilan tinggi bersifat final dan mengikat.

Selain UUPA dan Undang-undang Nomor 20 Tahun 1960, pemerintah dalam melaksanakan pengadaan tanah untuk kepentingan umum juga mendapatkan kewenangan atribusi dari Undang-undang Nomor 2 Tahun 2012 tentang pengadaan tanah bagi pembangunan untuk kepentingan umum sebagai dasar hukum yang menggantikan peraturan sebelumnya, yaitu Peraturan Presiden Nomor 65 Tahun 2006 tentang perubahan Peraturan Presiden Nomor 36 Tahun 2005 tentang pengadaan tanah bagi pembangunan untuk kepentingan umum. Munculnya Undangundang Nomor 2 Tahun 2012 diadasari oleh adanya kebutuhan yang mendesak untuk mengadakan tanah dalam rangka melakukan pembangunan infrastrukur, misalnya jalan tol, jembatan, bandara

16 Muhammad Yamin\& Abdul Rahim Lubis, Pencabutan Hak, Pembebasan, dan Pengadaan Tanah, (Bandung; Mandar Maju, 20I I), I 5. 
dan lainya, sementara produk hukum yang ada terdapat kelemahan dari sisi yuridisnya. Setidaknya ada dua kelemahan dari Peraturan Presiden Nomor 36 Tahun 2005, yaitu:

a. Kelemahan formil

Ketentuan Pasal 13 Undang-undang Nomor 12 Tahun 2011 tentang Pembentukan Peraturan Perundang-undangan (LN.201182,TLN.5234), yang menyatakan:"bahwa materi muatan Peraturan Presiden berisi materi yang diperintahkan oleh undang-undang atau materi untuk melaksanakan peraturan pemerintah atau materi untuk melaksanakan penyelenggaraan kekuasaan pemerintahan". Berdasarkan ketentuan tersebut, jelaslah bahwa peraturan presiden dibuat untuk melengkapi materi yang diperintahkan undangundang atau berisi materi yang diperintahkan oleh peraturan pemerintah. Artinya peraturan presiden sesungguhnya dibuat sebagai sarana administrasi pemerintah, namun menunjuk (according) undang-undang dan/atau peraturan pemerintah, sedangkan Peraturan Presiden Nomor 36 Tahun 2005, bukanlah merupakan materi yang diperintahkan oleh undang-undang atau materi untuk melaksanakan peraturan pemerintah, melainkan salah satu tindak lanjut Infrastructur Summit 2005, sehingga secara formil Peraturan Presiden Nomor 36 Tahun 2005 adalah cacat hukum dan harus dicabut.

b. Kelemahan materiil

Dari segi materiil, peraturan presiden tersebut bertentangan dengan Pasal 28H ayat (1) UUD 1945, dimana setiap orang tidak boleh dicabut hak miliknya secara sewenang-wenang, diakui memang bahwa Peraturan Presiden Nomor 36 Tahun 2005 adalah pilihan sulit, tetapi selalu dibayangi dengan kepentingan globalisasi dan percaloan oleh pejabat dan perorangan. Pembangunan demi 
kepentingan umum dikhawatirkan menjadi bias akibat permainan pejabat dan sepekulan tanah. ${ }^{17}$

Disamping itu, Peraturan Presiden Nomor 36 Tahun 2005 ini dianggap oleh para ahli sebagai produk hukum yang sangat represif, hal itu disebabkan antara lain karena munculnya Perpres tersebut dilatar belakangi oleh oleh kepentingan pemerintah dalam melaksakana pembangunan yang beridiologi kapitalis, sehingga lebih mementingkan kepentigan pemilik modal swasta daripada perlindungan terhadap masyarakat atas hak atas tanah yang dimiliknya. Hal itu dilakukan sebagai upaya untuk mendukung tercapainya pertumbuhan ekonomi. ${ }^{18}$ Jika dikaji secara mendalam subtansi Peraturan Presiden tersebut yang lebih didominasi kepentingan pengusaha dan pemilik modal swasta, hal itu bisa dilihat misalnya mengenai makna kepentingan umum yang hanya didefinisikan sebagai kepentingan sebagian besar masyarakat tanpa adanya pembatasan. Hal ini berbeda dengan produk hukum sebelumnya yakni yang diatur dalam Keputusan Presiden Nomor 55 Tahun 1993 yang memberikan batasan terhadap kepentingan umum, dengan tiga criteria, yaitu dimiliki oleh pemerintah, dikuasai pemerintah, dan tidak untuk mencari keuntungan. Beberapa ketentuan dalam Peraturan Presiden Nomor 36 Tahun 2005 yang bersifat represif yaitu;

"Pertama, mengenai pengaturan ganti rugi, dalam peraturan presiden tersebut hanya dinilai dari segi materiil, mestinya tidak hanya dinilai dari segi materiil. Perpres ini hanya menilai ganti rugi atas nilai tanah, tidak disebutkan ganti rugi tanaman yang tumbuh di atasnya atau nilai bangunan di atas tanah, tidak ada ketentuan bahwa ganti rugi itu menjamin kehidupan rakyat yang kehilangan tanah menjadi lebih baik.

Kedua, proses pengadaan tanah yang hanya dibatasai jangka waktu 90 hari. Pembatasan dalam jangka waktu 90 hari untuk negosiasi yang diatur dalam Perpres ini tidak memungkinkan

17 Musthofa\&Suratman, Penggunaan Hak Atas Tanah untuk Industri, (Jakarta: Sinar Grafika, 2013), 192-193.

$18 \mathrm{lbid}, 201$. 
pemegang hak atas tanah untuk menentukan pilihan-pilihan lain, kecuali dipaksa menerima ganti rugi yang ditetapkan, ketika sudah lewat 90 hari pemerintah diberikan kewenangan untuk melakukan pengadaan tanah meskipun tanpa kesepakatn dari pemilik tanah, melalui penitipan uang ganti rugi di pengadilan.

Ketiga, panitia pengadaan tanah, dalam peraturan presiden tersebut hanya mewakili pemerintah. Panitia pengadaan tanah ini dipastikan tak akan netral dan obyektif dalam melakukan negosiasi dalam pengadaan tanah. Tidak ada jaminan oknum dalam panitia pengadaan tanah ini tidak bermain mata dengan investor yang menyediakan modal untuk pembebasan lahan.." 19

Pengaturan ganti rugi yang hanya didasarkan pada kerugian fisik, pembatasan jangka waktu pelepasan hak yang hanya 90 hari, dan keberadaan panitia pengadaan tanah yang hanya mewakili kepentingan pemerintah menujukan bahwa Peraturan Presiden Nomor 36 Tahun 2005 sebagai produk hukum yang bersifat represif. Dalam hal ini perlu dilakukan perubahan; pertama, menambahkan ganti rugi tidak hanya pada kerugian fisik akan tetapi juga kerugian yang non fisik, misalnya dengan hilangnya pekerjaan akibat pengadaan tanah; kedua, memperpanjang jangka waktu musyawarah yang tidak hanya 90 hari akan tetapi lebih dari itu sampai terjadai kesepakatan antara pemerintah dengan pemilik tanah; ketiga, perlu dibentuk tim penilai (appraisal) yang bersifat obyektif dalam melakukan penilaian terhadap tanah dan bangunan, sehingga ganti rugi yang diterima oleh pemegang hak atas tanah merupakan ganti rugi yang sesuai dengan nilai tanah yang sebenarnya.

Atas dasar hal tersebut di atas, maka kemudian Peraturan Presiden Nomor 36 Tahun 2005 direvisi dengan Peraturan Presiden Nomor 65 Tahun 2006 tentang Perubahan Peraturan Presiden Nomor 36 Tahun 2005 tentang Pengadaan Tanah bagi Pembangunan untuk Kepentingan Umum. Beberapa Pasal yang diubah oleh Peraturan Presiden Nomor 65 tahun 2006 yaitu; Pasal 1 
ayat 3; Pasal 2 ayat 1; Pasal 3 ayat 2; Pasal 5; Pasal 6; Pasal 7; Pasal 10; Pasal 13; Pasal 15; dan Pasal 18. ${ }^{20}$ Namun demikian, perubahan tersebut perubahan tersebut belum menghilangkan sama sekali kelemahan dari Peraturan Presiden Nomor 36 tahun 2005, karena sifat represifnya juga masih telihat dalam perubahan Prepres tersebut.

Peraturan Presiden Nomor 65 Tahun 2006 tentang Perubahan Peraturan Presiden Nomor 36 Tahun 2005 tentang pengadaan tanah bagi pembangunan untuk kepentingan umum, jika dilihat dari bentuk hukumnya, tidak sesuai dengan Undang-undang Nomor 12 tahun 2011 tentang Pembentukan Peraturan Perundang-undangan (LN.2011-82,TLN.5234)..21 Materi yang dimuat dalam Peraturan Presiden tersebut seharusnya dimuat dalam bentuk undangundang, bukan dalam bentuk Peraturan Presiden. ${ }^{22}$ Disamping itu, Peraturan perundang-undangan sebelumnya dianggap belum memenuhi rasa keadilan bagi pihak yang kehilangan hak atas tanahnya. ${ }^{23}$ Atas dasar hal tersebut, kemudian Pemerintah mengesahkan Undang-undang Nomor 2 Tahun 2012 tentang Pengadaan Tanah bagi pembangunan untuk kepentingan umum (LN.2012-22,TLN.5280). Berdasarkan Undang-undang Nomor 2 Tahun 2012 dan Peraturan Presiden No 71 Tahun 2012 tentang Pelaksanaan pengadaan tanah untuk kepentingan umum,

\footnotetext{
20 Muwahid, "Pengadaan Tanah untuk Kepentingan Umum Yang Melibatkan pihak Swasta dalam Perspektif Hukum Islam" Jurnal ad Daulah, Vo. 7. No. I. April, 2017, 142

21 Ibid., I42.

22 Materi muatan dalam Peraturan Presiden berisi materi yang diperintahkan oleh Undang-undang, materi untuk melaksanakan Peraturan Pemerintah, atau materi untuk melaksanakan penyelenggaraan kekuasaan pemerintahan, sedangkan materi yang diatur dalam Undang-undang meliputi: pengaturan lebih lanjut mengenai ketentuan UUD 1945, perintah suatu Undang-undang untuk diatur dengan Undang-undang, pengesahan perjanjian internasional tertentu, tindak lanjut atas putusan Mahkamah Konstitusi, dan pemenuhan kebutuhan hukum dalam masyarakat. Lihat Pasal 10 dan 13 Undang-undang Nomor 12 Tahun 20 I I tentang Pembentukan Peraturan Perundangundangan.

${ }^{23}$ Peraturan Presiden Nomor 36 Tahun 2005 jo Peraturan Presiden Nomor 65 Tahun 2006 dianggap sebagai peraturan yang represif yang tidak memberikan perlindungan terhadap hak masyarakat atas tanahnya. Ganti kerugian yang diperhitungkan dalam Peraturan Presiden tersebut hanya ganti kerugian yang bersifat fisik, sedangkan kerugian yang non fisik tidak diperhitungkan, misalnya hilangnya mata pencaharian.
} 
pemerintah melaksanakan kegiatan pengadaan tanah untuk kepentingan umum.

Undang-undang No 2 Tahun 2012 ini yang dijadikan dasar oleh pemerintah dalam melakukan pengadaan tanah untuk kepentingan umum, undang-undang ini berbeda secara subtansi dengan peraturan sebelumnya, perbedaan yang paling mendasar adalah tidak dimungkinkanya dilakukan pencabutan hak atas tanah. Konsinyasi merupakan jalan terakhir ketika tidak tercapai kata sepakat antara pemilik hak atas tanah dengan pemerintah. Disamping itu dalam undang-undang ini dimungkinkan keterlibatan pihak swasta dalam pelaksanaan pembangunan untuk kepentingan umum sebagaimana diatur dalam pasal 12 ayat (1). Dengan kontruksi pemerintah yang menyediakan tanah, sedangkan swasta yang melaksanakan pembangunan, dan mengelola dalam jangka waktu tertentu melalui kerjasama pemerintah dengan swasta (KPS), atau Public Privat Partnership (PPP), seperti pembangunan rumah sakit, bandara, pelabuhan dan lainya.

\section{Inkonsistensi dan Overlapping Peraturan Perundang-undangan dalam Pengadaan Tanah}

Kontruksi hukum pengadaan tanah bagi pelaksanaan pembangunan untuk kepentingan umum dapat dilakukan melalui pelepasan hak atas tanah dengan musyawarah dan pencabutan hak atas tanah. Pelepasan hak atas tanah merupakan sebuah sarana untuk mendapatkan hak atas tanah yang dimiliki masyarakat melalui musyawarah untuk mencapai kesepakatan mengenai bentuk dan besarnya ganti kerugian, dengan memberikan ganti kerugian yang layak. ${ }^{24}$ Sedangkan pencabutan hak atas tanah merupakan sebuah sarana untuk mendapatkan hak atas tanah dari masyarakat dengan upaya paksa setelah musyawarah mufakat tidak menemui titik temu mengenai bentuk dan besarnya ganti rugi,

${ }^{24}$ Soedaryo Soimin, Status Hak dan Pembebasan Tanah, (Jakarta: Sinar Grafika, 200 I), 73. 
dalam pencabutan hak atas tanah kepada bekas pemegang hak atas tanah juga diberikan ganti kerugian yang layak. ${ }^{25}$

Istilah lain dari pelepasan hak adalah pembebasan tanah, ${ }^{26}$ keduanya mempunyai kesamaan pengertian hanya saja arah pandanganya yang berbeda. Kalau pembebasan tanah dilihat dari sudut pandangnya dari pihak yang mengambil tanah, sedangkan kalau pelepasan hak atas tanah dilihat dari sudut pandangya dari pihak yang melepaskan hak atas tanah. ${ }^{27}$ Pada pelepasan hak atas tanah unsur musyawarah untuk mencapai kata sepakat antara pemegang hak atas tanah dengan instansi Pemerintah yang memerlukan tanah merupakan syarat utama dalam acara perolehan hak atas tanah untuk kepentingan umum. Sedangkan dalam pencabutan hak atas tanah kesepakatan mengenai bentuk dan besarnya ganti kerugian tidak tercapai sedangkan tidak mungkin diperoleh tanah di tempat yang lain, sehingga dalam pencabutan hak atas tanah mengandung unsur paksaan sepihak dari pemerintah.

Pelaksanaan pembangunan untuk kepentingan umum dilakukan oleh pemerintah dengan seperangkat peraturan perundang-undangan yang melegitimasi tindakan Pemerintah dalam melakukan pengadaan tanah untuk kepentingan umum, baik melalui pelepasan hak atas tanah atau melalui pencabutan hak atas tanah. Peraturan Perundang-undangan yang dimaksud antara lain: (1).Undang-undang Nomor 20 Tahun 1961 tentang Pencabutan Hak atas Tanah dan Benda-benda yang ada di Atasnya; (2).

\footnotetext{
${ }^{25}$ Effendi Perangin, Hukum Agraria...,38.

${ }^{26}$ Istilah pembebasan tanah merupakan istilah yang diatur untuk pertama kalinya dalam PMDN No. 15 Tahun 1975 tentang Ketentuan-ketentuan mengenai Tata Cara Pembebasan Tanah. Pembebasan tanah menurut PMDN No. 15 Tahun 1975 ialah melepaskan hubungan antara pemegang hak atas tanah dengan tanah yang dikuasainya dengan memberikan ganti rugi. Kemudian istilah "pembebasan tanah" dalam Keppres No. 55 Tahun 1993, Perpres Nomor 36 Tahun 2005 jo Perpres Nomor 65 Tahun 2006 dan Undang-undang Nomor 2 Tahun 2012 diganti dengan "pengadaan tanah".

27 Netty Endrawati, "Pengadaan Tanah Untuk Kepentingan Pembangunan Nasional Menurut Keppres No. 55 Tahun 1993 jo Keppres No. 34 Tahun 2003", dalam Jurnal Legality, Vol 12 No. 2 Sep 2004- Feb 2005, h. 266.
} 
Undang-undang Nomor 2 Tahun 2012 tentang Pengadaan Tanah bagi Pembangunan untuk Kepentingan Umum; (3). Peraturan Pemerintah Nomor 39 Tahun 1973 tentang Acara Penetapan Ganti Kerugian Oleh Pengadilan Tinggi Sehubungan dengan Pencabutan Hak Atas Tanah dan Benda-benda yang Ada di Atasnya; (4). Peraturan Presiden Nomor 71 Tahun 2012 tentang Penyelanggaraan Pengadaan Tanah Bagi Pembangunan untuk Kepentingan Umum; (5). Intruksi Presiden Nomor 9 Tahun 1973 tentang Pedoman Pelaksanaan Pencabutan Hak Atas Tanah dan Benda-benda yang Ada di Atasnya.

Peraturan perundang-undangan dalam pengadaan tanah untuk kepentingan umum idealnya harus sinkron, konsisten, harmonis dan tidak terdapat kontradiksi pengaturan antara pasalpasal dalam peraturan yang sama, atau antara pasal-pasal dalam peraturan perundang-undangan yang berbeda, baik secara vertical maupun secara horizontal. Namun demikian, jika dikaji pengaturan pengadaan tanah untuk kepentingan umum antara berbagai peraturan perundang-undangan sebagaimana disebut di atas terdapat beberapa persoalan hukum (problem yuridis), yaitu:

Pertama, tidak adanya sinkronisasi antara Undang-undang Nomor 2 Tahun 2012 tentang Pengadaan Tanah Untuk Kepentingan Umum dengan Undang-undang Nomor 20 Tahun 1961 tentang Pencabutan Hak Atas Tanah dan Benda-benda yang Ada di Atasnya. Undang-undang Nomor 2 tahun 2012 menafikan keberadaan Undang-undang Nomor 20 tahun 1961, dalam Undangundang Nomor 2 Tahun 2012 tidak ada satupun pasal yang mengamanatkan dilakukan pencabutan hak atas tanah berdasarkan Undang-undang Nomor 20 Tahun 1961, apabila tidak tercapai kata sepakat mengenai bentuk dan besarnya ganti kerugian setelah dilakukan musyawarah. Padahal dalam kontuksi hukum pengadaan tanah, apabila tidak terjadi kesepakatan mengenai bentuk dan besarnya ganti rugi, Gubernur dapat melakukan usul pencabutan hak atas tanah kepada Presiden. Dalam ilmu hukum salah satu prinsip dasar adalah hukum sebagai sistem, artinya 
hukum itu merupakan satu kesatuan, sebuah tatanan yang utuh yang terdiri dari komponen-komponen dan unsure-unsur yang berkaitan. Sistem hukum itu bersifat ajek, tidak berubah, meskipun peraturan perundang-undanganya berubah, sistemnya tetap sama, berkesinambungan dan otonom, sistem yang dimaksud adalah ketika proses musyawarah tercapai kata sepakat maka melalui mekanisme pelepasan hak, sedangkan apabila tidak tercapai kata sepakat maka melalui pencabutan hak. ${ }^{28}$ Dengan demikian, walaupun peraturan perundangan yang mengatur masalah pengadaan tanah untuk kepentingan umum berubah-ubah, namun sistemnya selalu sama, kontinyu, dan tetap, yakni kontruksi hukumnya melalui pengadaan tanah jika tercapai kesepakatan melalui musyawarah, dan melalui pencabutan hak apabila tidak tercapai kesepakatan dalam musyawarah. ${ }^{29}$ Dengan catatan proyek pembangunan tidak bisa dipindahkan ke tempat lain, namun jika masih bisa dipindahkan ke tempat lain, pencabutan hak atas tanah sebaiknya dihindari. Dalam Undang-undang Nomor 2 Tahun 2012, apabila musyawarah tidak menemui titik temu pemegang hak atas tanah diberikan hak untuk mengajukan keberatan ke Pengadilan Negeri, jika tidak terima dengan putusan Pengadilan Negeri, pemegang hak atas tanah diberikan hak untuk mengajukan kasasi Ke Mahkamah Agung, putusan Mahkamah Agung bersifat final dan mengikat, artinya jika pemegang hak atas tanah tidak menerima putusan Mahkamah Agung, pemerintah dapat melakukan pengadaan tanah dengan cara menitipkan uang ganti ruginya di Pengadilan Negeri (konsinyasi), ${ }^{30}$ Konsinyasi ini

\footnotetext{
${ }^{28}$ Sudikno Mertokusumo, Mengenal Hukum, (Yogyakarta: Liberty, 2003), I I 5.

29 Maria S.W. Sumardjono, "Anatomi UU No 2 Tahun 2012 tentang Pengadaan Tanah bagi Pembangunan untuk Kepentingan Umum Tinjauan Filosofis, Yuridis, dan Sosiologis", Makalah disampaikan pada Sosialisasi Undang-Undang Nomor 2 Tahun 2012, diselenggarakan oleh Direktorat Utama Bidang Pembinaan dan Pengembangan Hukum Pemeriksaan Keuangan RI, Jakarta, 22 Maret 2012, 19.

${ }^{30}$ Konsep Konsinyasi dalam pengadaan tanah sebenarnya mengadopsi konsep konsinyasi yang diatur dalam Pasal I 404 KUHPerdata, jika kreditor menolak pembayaran dari debitor, maka debitor diperkenankan menitipkan pembayaran utangnya tersebut di Pengadilan Negeri. Dalam hukum
} 
merupakan jalan terakhir, ${ }^{31}$ hal ini berbeda dengan peraturan perundangan sebelumya, yakni Peraturan Presiden Nomor 65 Tahun 2006 dan Peraturan Presiden Nomor 36 Tahun 2005, dan Keputusan Presiden Nomor 55 Tahun 1993. Dalam ketiga peraturan perundangan tersebut, jika pemegang hak atas tanah tidak menerima ganti rugi yang diberikan oleh pemerintah, pemegang hak atas tanah dapat mengajukan keberatan kepada Gubernur/Bupati/Walikota, kemudian Gubernur/Bupati/Walikota akan memberikan keputusan mengenai besar dan bentuk ganti rugi. Apabila pemegang hak atas tanah tetap keberatan dengan keputusan Gubernur/Bupati/Walikota, maka Gubernur/Bupati/Walikota mengajukan usul pencabutan hak atas tanah kepada Presiden, kemudian Presiden melakukan pencabutan hak atas tanah berdasarkan Undang-undang Nomor 20 Tahun 1961.

Kedua, adanya overlapping pengaturan antara Pasal 49 Undangundang Nomor 2 Tahun 2012 dengan Pasal 6 Undang-undang Nomor 20 Tahun 1961.

Pasal 49 Undang-undang Nomor 2 Tahun 2012 menentukan:

1. Pengadaan tanah untuk kepentingan umum karena keadaan mendesak akibat bencana alam, perang, konflik sosial yang meluas, dan wabah penyakit dapat langsung dilaksanakan pembangunannya setelah dilakukan penetapan lokasi pembangunan untuk kepentingan umum.

2. Sebelum penetapan lokasi pembangunan untuk kepentingan umum sebagaimana dimaksud pada ayat (1), terlebih dahulu disampaikan pemberitahuan kepada pihak yang berhak.

3. Dalam hal terdapat keberatan atau gugatan atas pelaksanaan pengadaan tanah, Instansi yang memerlukan tanah tetap dapat

perdata konsinyasi merupakan salah satu sebab yang menghapus perikatan lihat Pasal I38 I KUHPerdata.

${ }^{3}$ 'Lihat ketentuan Pasal 42 (I) Undang-undang Nomor 2 Tahun 2012 tentang Pengadaan Tanah bagi Pelaksanaan Pembangunan untuk Kepentingan Umum. 
melaksanakan kegiatan pembangunan sebagaimana dimaksud pada ayat (1).

Ketentuan yang terdapat dalam Pasal 49 Undang-undang Nomor 2012 ini sebenarnya sudah masuk dalam pengaturan pencabutan hak atas tanah dalam keadaan mendesak, sebagaimana diatur dalam Pasal 6 Undang-undang Nomor 20 Tahun 1961. Pasal 6 Undang-undang Nomor 20 Tahun 1961 menentukan:

1. Menyimpang dari ketentuan Pasal 3, maka dalam keadaan yang sangat mendesak yang memerlukan penguasaan tanah dan/atau benda-benda yang bersangkutan dengan segera, atas permintaan yang berkepentingan Kepala Inspeksi Agraria menyampaikan permintaan untuk melakukan pencabutan hak tersebut pada Pasal 2 kepada Menteri Agraria, tanpa disertai taksiran ganti kerugian Panitia Penaksir dan kalau perlu juga dengan tidak menunggu dterimanya pertimbangan Kepala Daerah.

2. Dalam hal tersebut pada ayat (1) pasal ini, Menteri Agraria dapat mengeluarkan surat keputusan yang memberi perkenan kepada yang berkepentingan untuk menguasai tanah dan/atau bendabenda yang bersangkutan. Keputusan penguasaan tersebut akan segera diikuti dengan Keputusan Presiden mengenai dikabulkan atau ditolaknya permintaan untuk melakukan pencabutan hak itu.

3. Jika telah dilakukan penguasaan atas dasar surat keputusan tersebut pada ayat (2) pasal ini, maka bilamana permintaan pencabutan haknya tidak dikabulkan, yang berkepentingan harus mengembalikan tanah dan/atau benda-benda yang bersangkutan dalam keadaan semula dan/atau memberi ganti kerugian yang sepadan kepada yang mempunyai hak.

Di samping itu dalam Penjelasan Umum Angka 4 Undangundang Nomor 20 Tahun 1961 juga menentukan:

“....Dalam keadaan yang sangat mendesak yang memerlukan penguasaan tanah dan /atau benda-benda yang bersangkutan dengan segera, maka pencabutan hak khususnya penguasaan 
tanah dan/atau benda itu dapat diselenggarakan melalui acara khusus yang lebih cepat. Keadaan yang sangat mendesak itu misalnya jika terjadi wabah atau bencana alam yang memerlukan penampungan para korbanya dengan segera. Dalam hali ini maka permintaan untuk melakukan pencabutan hak dajukan oleh kepala Inspeksi agrarian kepada Menteri Agraria tanpa disertai taksiran ganti kerugian Panitia Penaksir dan kalau perlu dengan tidak menunggu diterimanya pertimbangan Kepala Daerah. Menteri Agraria kemudian dapat memberikan perkenan kepada yang berkepentingan untuk segera menguasai tanah dan/atau benda tersebut biarpun belum ada keputusan mengenai permintaan pencabutan haknya dang anti kerugiaannya pun belum dibayar."

Dengan adanya overlapping pengaturan tersebut akan terjadi kerancuan mengenai kewenangan dalam pengadaan tanah dalam keadaan mendesak, apakah itu merupakan kewenangan Gubenur berdasarkan Undang-undang Nomor 2 Tahun 2012 atau kewenangan Presiden berdasarkan Undang-undang Nomor 20 Tahun 1961. Untuk menyelesaikan hal tersebut maka harus dilihat dari perspektif ilmu hukum dan ilmu Perundang-undangan.

Dalam ilmu hukum dikenal mengenai asas-asas dalam peraturan perundang-undangan, dengan berpedoman pada asasasas tersebut dapat diselesaikan mengenai overlapping, dan disharmoni antar peraturan perundang-undangan. Bertolak dari kerangka pemikiran sistem hukum, peraturan perundangundangan sebagai suatu subsistem dan komponen sistem hukum nasional memiliki asas yang terintegrasi dan dijiwai Pancasila dan UUD NRI 1945, sehingga menjadi sistem hukum nasional yang harmonis, dalam arti selaras, serasi, seimbang dan konsisten serta tidak bertentangan di antara peraturan perundang-undangan, baik secara vertikal maupun secara horizontal. Langkah ideal dalam harmonisasi hukum adalah upaya menyelaraskan, menyerasikan, menyesuaikan, menyeimbangkan dan konsistensi unsur-unsur sistem hukum dalam rangka mengintegrasikan bebagai sistem 
hukum sehingga tersusun dalam satu tatanan yang harmonis satu sama laindalam kerangka sistem hukum nasional. ${ }^{32}$

Jika dalam suatu peraturan perundang-undangan terjadi disharmonisasi norma atau pertentangan peraturan perundangundangan, maka diselesaikan dengan asas-asas hukum yang berlaku, yaitu:

1. Asas lex specialis derogat legi generalis; peraturan hukum yang khusus mengesampingkan peraturan yang umum, dengan syarat:

a. Ketentuan yang di dapat dalam ketentuan hukum umum tetap berlaku, kecuali yang diatur khusus dalam aturan hukum khsusus tersebut;

b. Ketentuan lex specialis harus sederajat dengan ketentuan lex generali;

c. Ketentuan lex specialis harus berada dalam lingkungan hukum yang sama dengan lex generalis.

2. Asas lex posterior derogat legi preiori: peraturan hukum yang baru mengesampingkan atau meniadakan peraturan hukum yang lama, dengan syarat:

a. Peraturan hukum yang baru harus sederajat atau lebih tinggi dari aturan hukum yang lama;

b. Peraturan hukum yang baru dan yang lama mengatur obyek yang sama.

3. Asas lex supperiori derogat legi inferiori: peraturan yang lebih tinggi mengesampingkan peraturan yang lebih rendah. ${ }^{33}$

Penerapan asas lex supperiori derogat legi inferiori dalam aplikasinya terdapat pengecualian sebagai berikut:

"Peraturan perundang-undangan yang lebih tinggi mengesampingkan peraturan perundang-undangan lebih rendah kecuali subtansi peraturan perundang-undangan lebih tinggi

${ }^{32}$ Teguh Prasetyo\& Abdul Halim B., Filsafat, Teori\&llmu Hukum, (Jakarta: PT. Rajagrafindo, 20I2), 333.

33 Wicipto Setiadi et al, Pedoman Pengharmonisan, Pembulatan dan Pemantapan Konsepsi Rancangan Peraturan Perundang-undangan, (Jakarta: Direktorat Jenderal Peraturan Perundangundangan, 20I0), 98. 
mengatur hal-hal yang oleh undang-undang ditetapkan menjadi wewenang peraturan perundang-undangan tingkat lebih rendah. Peraturan Pemerintah yang kedudukannya lebih tinggi dari Peraturan Daerah tidak selamanya Peraturan Daerah yang bertentangan dengan Peraturan Pemerintah dikesampingkan dan dinyatakan batal atau tidak sah, kalau ternyata materi muatan Peraturan Pemerintah mengatur hal-hal yang menjadi wewenang daerah, dan materi muatan Peraturan Daerah berada dalam wewenang daerah, maka Peraturan Pemerintah yang harus mengalah bukan Peraturan Daerah" ${ }^{34}$

Jika suatu peraturan dianggap bertentangan dengan peraturan yang lebih tinggi maka untuk memastikan keabsahannya bisa dilakukan melalui pengujian oleh lembaga yudikatif, yaitu dilakukan oleh Mahkamah Agung apabila yang diuji peraturan yang kedudukanya di bawah undang-undang, misalnya Peraturan Pemerintah, Peraturan Presiden dan Peraturan Daerah. Apabila yang diuji itu adalah undang-undang terhadap Undang-Undang Dasar, maka lembaga yang berwenang melakukan uji materi (yudicial review) adalah Mahkamah Konstitusi. (MK), Istilah pengujian itu sendiri mencakup uji materiil dan uji formal. Uji materiil dilakukan berkenaan dengan isinya yang dianggap bertentangan dengan peraturan perundang-undangan yang lebih tinggi, sedangkan uji formal dilakukan berkenaan dengan prosedurnya yang dianggap melanggar atau salah. ${ }^{35}$

Dalam persoalan overlapping pengaturan antara Undangundang Nomor 2 Tahun 2012 dengan Undang-undang Nomor 20 Tahun 1961, maka bisa diselesaikan dengan asas lex posterior derogat legi priori: peraturan hukum yang baru mengesampingkan atau meniadakan peraturan hukum yang lama, jika memakai asas ini maka yang harus dipedomani adalah Undang-undang Nomor 2

34 Rafael Tunggu, "Pengaturan Hak Penguasaan Tanah Pertanian oleh Korporasi Berbasis Perlindungan Hak-Hak Ekonomi Rakyat dalam Konteks Negara Hukum Kesejahteraan Indonesia", Disertasi, Program Doktor Ilmu Hukum Fakultas Hukum Universitas Brawijaya, Malang, 2012, 57. 35 Moh. Mahfud MD, Konstitusi dan Hukum dalam Kontroversi Isu, (Jakarta: Rajawali Press, 2009), 257 
Tahun 2012 sebagai hukum yang baru. Namun yang menjadi persoalan dalam praktik adalah bahwa sebuah hukum akan tetap berlaku apabila secara formiil belum dicabut oleh undang-undang yang baru. Dalam Undang-undang Nomor 2 Tahun 2012 tidak ada satu pasalpun yang memerintahkan untuk mencabut atau setidaknya menyatakan tidak berlaku Undang-undang Nomor 20 Tahun 1961 sepanjang sudah diatur dalam Undang-undang Nomor 2 Tahun 2012.

\section{Penutup}

Kewenangan merupakan kekuasaan yang diformalkan baik terhadap segolongan orang tertentu, maupun kekuasaan terhadap suatu bidang pemerintahan secara bulat yang berasal dari kekuasaan legislative maupun kekuasaan pemerintah. Sedangkan wewenang merupakan kemampuan untuk melakukan tindakan hukum tertentu, dalam arti tindakan yang mempunyai akibat hukum. Wewenang pemerintah dalam menjalankan administrasi negara diperoleh melalui tiga cara, yaitu atribusi, delegasi, dan mandat. Atribusi merupakan kewenangan yang diperoleh dari peraturan perundang-undangan, delegasi merupakan kewenangan yang diperoleh dari limpahan pejabat yang lain, sedangkan mandat kewenangan yang diperoleh dari pejabat yang lain dalam hubungan atasan dan bawahan.

Pemerintah dalam melaksanakan pengadaan tanah untuk kepentingan umum mendapatkan kewenangan atribusi dalam Undang-undang Nomor 5 Tahun 1960 tentang peraturan dasar pokok-pokok Agraria pasal 2, pasal 6, dan pasal 18, kemudian pemerintah juga mendapatkan kewenangan atribusi dari Undangundang Nomor 20 Tahun 1961 tentang pencabutan hak atas tanah, dan Undang-undang Nomor 2 Tahun 2012 tentang pengadaan tanah bagi pembangunan untuk kepentingan umum.

Pengaturan dalam Undang-undang Nomor 2 Tahun 2012 dengan Undang-undang Nomor 20 Tahun 1961 terdapat inkonsistensi. Beberapa pasal dalam Undang-undang Nomor 2 
tahun 2012 menafikan ketentuan yang diatur dalam Undangundang Nomor 20 tahun 1961. Padahal secara formil Undangundang Nomor 20 tahun 1961 masih berlaku karena belum pernah dicabut atau diganti dengan peraturan perundang-undangan yang lain. Disamping itu terjadi overlapping pengaturan antara Pasal 49 Undang-undang Nomor 2 Tahun 2012 dengan Pasal 6 Undangundang Nomor 20 Tahun 1961, sehingga terjadi kerancauan dalam praktiknya antara menggunakan intsrumen pengadaan tanah atau pencabutan hak atas tanah.

\section{Daftar Pustaka}

AP. Parlindungan, Bunga Rampai Hukum Agraria Serta Land Reform, Bandung: CV Mandar Maju, 1994.

Boedi Harsono, Hukum Agraria Indonesia, Sejarah Pembentukan Undang-Undang Pokok Agraria, Isi dan Pelaksanaannya, Jakarta: Djambatan, 2000.

Effendi Perangin, Hukum Agraria di Indonesia, Suatu Telaah dari Sudut Pandang Praktisi Hukum, Jakarta: Rjawali Press, 1991.

Maria SW Soemardjono, Kebijakan Pertanahan Antara Regulasi dan Implementasi, Jakarta: Penerbit Buku Kompas, 2005.

Muhammad Yamin\& Abdul Rahim Lubis, Pencabutan Hak, Pembebasan, dan Pengadaan Tanah, Bandung; Mandar Maju, 2011. Moh. Mahfud MD, Konstitusi dan Hukum dalam Kontroversi Isu, Jakarta: Rajawali Press, 2009.

Maria S.W. Sumardjono, “Anatomi UU No 2 Tahun 2012 tentang Pengadaan Tanah bagi Pembangunan untuk Kepentingan Umum Tinjauan Filosofis, Yuridis, dan Sosiologis", Makalah disampaikan pada Sosialisasi Undang-Undang Nomor 2 Tahun 2012, diselenggarakan oleh Direktorat Utama Bidang Pembinaan dan Pengembangan Hukum Pemeriksaan Keuangan RI, Jakarta, 22 Maret 2012.

Muwahid, "Pengadaan Tanah untuk Kepentingan Umum Yang Melibatkan pihak Swasta dalam Perspektif Hukum Islam" Jurnal ad Daulah, Vo. 7. No. 1. April, 2017. 
Musthofa\&Suratman, Penggunaan Hak Atas Tanah untuk Industri, Jakarta: Sinar Grafika, 2013.

Ridlwan HR, Hukum Administrasi Negara, Jakarta: PT. Rajagrafindo Persada, 2011.

Rafael Tunggu, "Pengaturan Hak Penguasaan Tanah Pertanian oleh Korporasi Berbasis Perlindungan Hak-Hak Ekonomi Rakyat dalam Konteks Negara Hukum Kesejahteraan Indonesia", Disertasi, Program Doktor Ilmu Hukum Fakultas Hukum Universitas Brawijaya, Malang, 2012.

Sadjiono, Bab-bab Pokok Hukum Administrasi Negara, Yogyakarta: LaksBang, 2011.

S.F. Marbun, Peradilan Admintrasi Negara dan Upaya Administratif di Indonesia, Yogyakarta; Liberty, 1997.

Yusriadi, IndustrialisasiEPerubahan Fungsi Sosial Hak Milik Atas Tanah, (Yogyakarta: Genta Publising, 2010.

Soedaryo Soimin, Status Hak dan Pembebasan Tanah, Jakarta: Sinar Grafika, 2001.

Sudikno Mertokusumo, Mengenal Hukum, Yogyakarta: Liberty, 2003.

Teguh Prasetyo\& Abdul Halim B., Filsafat, TeoriEIlmu Hukum, Jakarta: PT. Rajagrafindo, 2012.

Wicipto Setiadi et al, Pedoman Pengharmonisan, Pembulatan dan Pemantapan Konsepsi Rancangan Peraturan Perundang-undangan, Jakarta: Direktorat Jenderal Peraturan Perundang-undangan, 2010.

Undang-undang No 5 Tahun 1960 tentang Peraturan Dasar Pokok Agraria (UUPA).

Undang-undang No 20 Tahun 1961 tentang Pencabutan Hak Atas Tanah dan Benda-benda Yang Ada di Atasnya (UUPHAT).

Undang-undang No 2 Tahun 2012 tentang Pengadaan Tanah bagi Pembangunan Untuk Kepentingan Umum (UUPTKU). 